\title{
Circulating MicroRNAs as Prognostic and Therapeutic Biomarkers in Breast Cancer Molecular Subtypes
}

\author{
Veronica Zelli ${ }^{1,2}$, Chiara Compagnoni $^{1}$, Roberta Capelli ${ }^{1}$, Katia Cannita ${ }^{3}$, Tina Sidoni ${ }^{3}$, \\ Corrado Ficorella ${ }^{3}$, Carlo Capalbo ${ }^{4} \mathbb{D}$, Francesca Zazzeroni ${ }^{1}$, Alessandra Tessitore ${ }^{1,2, *, \dagger}$ and \\ Edoardo Alesse ${ }^{1,+}$
}

1 Department of Biotechnological and Applied Clinical Sciences, University of L'Aquila, Via Vetoio, Coppito 2, 67100 L'Aquila, Italy; veronica.zelli@univaq.it (V.Z.); chiara.compagnoni@graduate.univaq.it (C.C.); roberta.capelli@graduate.univaq.it (R.C.); francesca.zazzeroni@univaq.it (F.Z.); edoardo.alesse@univaq.it (E.A.)

2 Center for Molecular Diagnostics and Advanced Therapies, University of L'Aquila, Via Petrini, 67100 L'Aquila, Italy

3 Medical Oncology Unit, St Salvatore Hospital, Via L. Natali, 1, 67100, L'Aquila, Italy; kcannita@gmail.com (K.C.); tina_sidoni@yahoo.it (T.S.); corrado.ficorella@univaq.it (C.F.)

4 Department of Molecular Medicine, University of Rome "La Sapienza", Viale Regina Elena 324, 00161 Rome, Italy; carlo.capalbo@uniroma1.it

* Correspondence: alessandra.tessitore@univaq.it; Tel.: +39-0862433518; Fax: +39-0862433131

+ These authors contributed equally to the work as co-last authors.

Received: 6 August 2020; Accepted: 20 August 2020; Published: 22 August 2020

\begin{abstract}
Breast cancer (BC) is a common and heterogeneous disease, of which six molecular subtypes, characterized by different biological features and clinical outcomes, were described. The identification of additional biomarkers able to further connote and distinguish the different $\mathrm{BC}$ subtypes is essential to improve the diagnostic, prognostic and therapeutic strategies in BC patients. MicroRNAs (miRNAs) are short non-coding RNA involved in several physiological and pathological processes, including cancer development and progression. In particular, circulating miRNAs, which can be found in an adequately stable structure in serum/plasma of cancer patients, are emerging as very promising non-invasive biomarkers. Several studies have analyzed the potential role of circulating miRNAs as prognostic and therapeutic markers in BC. In the present review we describe circulating miRNAs, identified as putative biomarker in $\mathrm{BC}$, with special reference to different $\mathrm{BC}$ molecular subtypes.
\end{abstract}

Keywords: breast cancer; molecular subtypes; microRNA; circulating microRNA; biomarkers

\section{Introduction}

Breast cancer (BC) is the most common cancer in women and the leading cause of cancer-related death [1], representing a serious concern for public health. At the molecular and clinical level, $\mathrm{BC}$ comprises heterogeneous forms, and the advancement of knowledge in the field showed that accurate molecular classification is necessary to significantly improve prognosis and treatment choice [2]. To date, six major BC molecular subtypes (Luminal A, Luminal B, HER2 positive, basal-like (triple negative), normal-like and claudin-low), characterized by different molecular features and clinical outcomes, were identified [3].

MicroRNAs (miRNAs) are short, single-stranded non-coding RNAs that regulate gene expression at the post-transcriptional level, the dysregulated expression of which is involved in some high-impact diseases, such as cancer $[4,5]$. In the last few years, great attention was addressed to the role of miRNAs 
as potential biomarkers in cancer: in particular, circulating miRNAs can be released from the tumor microenvironment and poured into the bloodstream, where they are stable and resistant to endogenous RNase activity [6], thus reflecting the homeostatic response of the organism to disease development and progression. For this reason, they are considered potential diagnostic, prognostic and therapeutic non-invasive biomarkers [7].

BC epigenetic mechanisms are not completely elucidated, but it is now undeniable that miRNAs play an important role in BC pathogenesis and progression, being able to specifically fine-tune different types of key genes with oncogenic, tumor suppressive properties, or also acting in DNA repairing mechanisms [8]. An increasing number of studies have focused on shedding light on the correlation between the complex biology of miRNA expression and BC features, with reference to the different types, clinical presentation, behavior, heterogeneous structure of tissues and gene expression profiles. Many studies have described the significant differential expression levels of groups of miRNAs with potential diagnostic/prognostic value in tissues or sera from BC patients-among them, several were also described as putatively playing a role in predicting BC therapy response $[2,9,10]$.

The aim of this review is to provide an overview of the role of circulating miRNAs as prognostic and therapeutic biomarkers in BC, with focus on the different BC molecular subtypes.

\section{Breast Cancer}

$\mathrm{BC}$ is the most diagnosed cancer in women worldwide, accounting for about $11.6 \%$ of all cancer cases and $6.6 \%$ of all cancer-related deaths [1]. The annual incidence of BC is estimated at more than 2 million new cases, with the highest rates observed in Australia/New Zealand, Europe, and Northern America [1].

The most classical criteria for BC clinical management are tumor size, lymph-node status, presence of distant metastasis, expression of estrogen and progesterone receptors (ER, PR), expression level of human epithelial growth factor receptor 2 (HER2) [11,12]. In the last few decades, technical advancement focused on gene expression analysis made breast tumor classification possible, based on their own molecular features, leading to the generation of six major subgroups, characterized by differences in aggressiveness: Luminal A, Luminal B, HER2 positive, TN (triple negative, or basal-like), normal-like and, more recently, claudin-low [13-16].

The luminal subtype, mainly dominated by hormone receptor positive $(\mathrm{HR}+)$ tumors, and generally $\mathrm{ER}+, \mathrm{PR}+, \mathrm{HER} 2$ negative (HER2-), is the most common BC profile, accounting for about $60 \%$ of all BC tumors [17]. Compared to Luminal A, showing the most favorable prognosis, the Luminal B subgroup is characterized by higher recurrence risk, due to the expression of genes involved in cell proliferation (Ki67/MIB1). Depending on HER2 expression, Luminal B tumors can be further split into Luminal B/HER2+ and Luminal B/HER2- [3,12].

TN and HER2+ subtypes are characterized by HR- enriched tumors; in particular, the TN subtype lacks ER, PR, HER2 expression and shows cytokeratin (CK5/6, CK14) expression increase, whereas the HER2+ subgroup is dominated by tumors with a high expression of HER2 and HR loss [3,12,17]. Due to the above-mentioned molecular features, HER2+ tumors can benefit from anti-HER2 targeted therapy (trastuzumab, lapatinib), whereas TNBCs show the worst prognosis and are currently not eligible for any biological treatment.

Furthermore, in the normal-like subtype, a gene expression pattern similar to normal breast tissue was observed [3], whereas the claudin-low type is a less common and aggressive BC, mainly characterized by TN tumors with epithelial-to-mesenchymal transition features, immune response and cancer stem cell-like markers [16]. Overall, the advancement of knowledge of molecular mechanisms at the base of $\mathrm{BC}$, leading to $\mathrm{BC}$ molecular classification, made the development and adoption of specific drugs for personalized medicine possible, greatly improving prognosis and BC tailored treatment (Figure 1). 


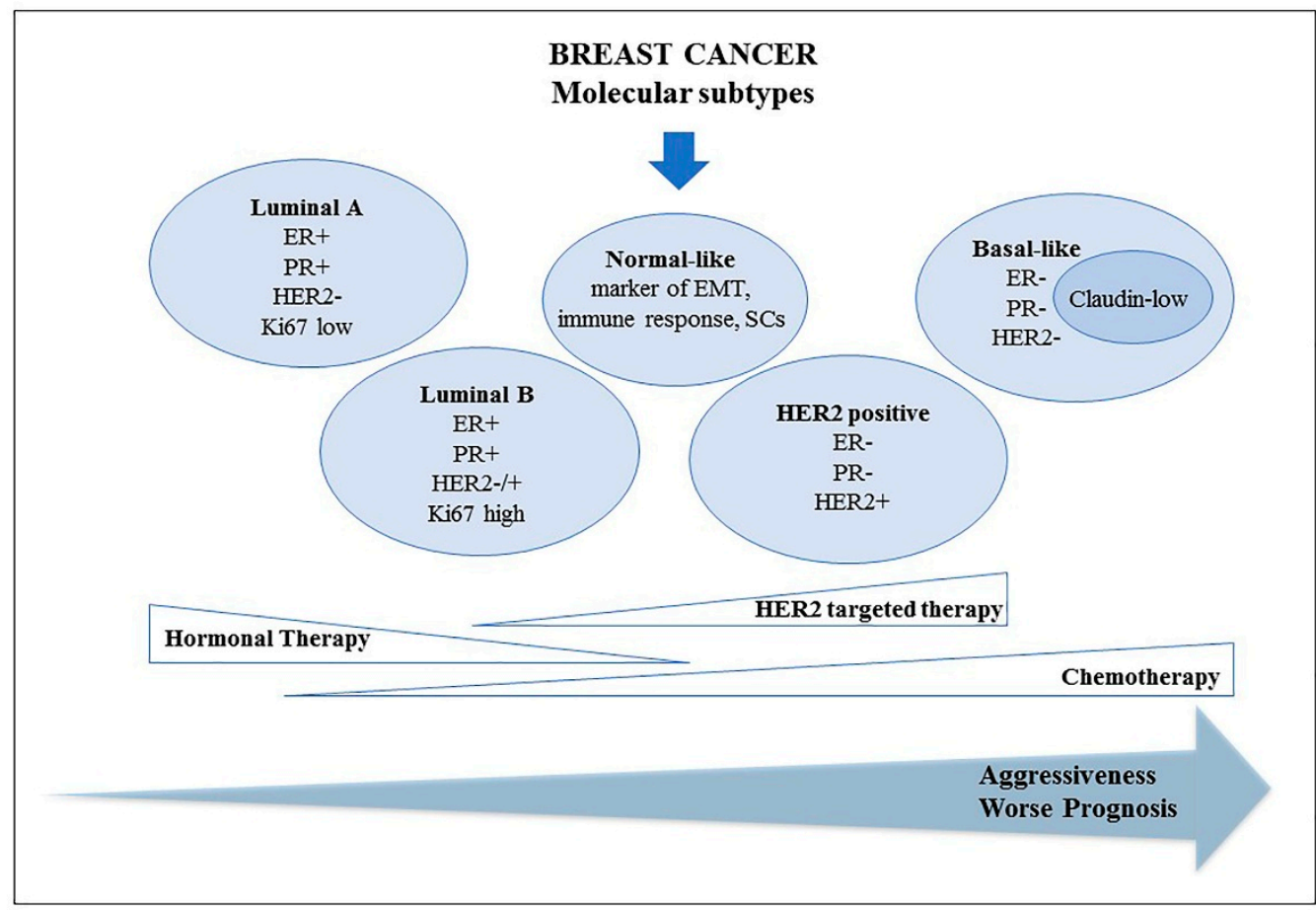

Figure 1. Classification of breast cancer molecular subtypes. Abbreviations: ER+, estrogen receptor positive; $\mathrm{PR}+$, progesterone receptor positive; HER2+, human epithelial growth factor receptor 2 positive; EMT, epithelial-to-mesenchymal transition; SCs, stem cells.

Differences related to mutational landscape as well as a combination of gene expression patterns and copy number alterations were also observed among different BC cases, identifying subgroups of tumors characterized by similarities in somatic alterations [18-20], some of which were specific for the different molecular subtypes, described above [19,21,22]. Molecular profiling tools, such as Oncotype DX, MammaPrint, Prosigna, Endopredicit and Breast Cancer Index, are in use to predict $\mathrm{BC}$ prognosis and therapy response. In this regard, validation data of three extensive randomized prospective studies to select ER+/HER2- patients who could benefit from adjuvant chemotherapy plus endocrine therapy are available: two of them (TAILORx, RxPONDER) used Oncotype DX (21 relevant genes by qRT-PCR) which classified ER+ cancers in three groups based on "recurrence scores" [23,24]; the third study (MINDACT) used MammaPrint (70 genes by microarray) to define BCs with high and low recurrence risk $[25,26]$. However, more light can be shed on factors able to better refine $\mathrm{BC}$ molecular subtypes and identify novel non-invasive biomarkers with diagnostic, prognostic and predictive value. In this context, microRNAs are considered among the most promising molecules.

\section{Circulating MiRNAs: From Tumor to Bloodstream}

MiRNAs are short (18-22 nucleotides), single-stranded non-coding RNAs involved in the post-transcriptional regulation of specific target genes [27,28]. MiRNAs play a crucial role in several biological processes, such as cell cycle regulation and differentiation, apoptosis, metabolism and cell signaling [29-31]. On the other hand, the alteration of their expression may significantly contribute to the pathogenesis of many relevant diseases, including the development and progression of cancer. Depending on the role of their own target genes, miRNAs with oncogenic (oncomiR) or tumor suppressive (tumor suppressor miR) properties have been described at the tissue level [4]. In addition, the dysregulated miRNAs produced in the tumor microenvironment can be released into the bloodstream because of passive (apoptosis or necrosis of cancer cells) or active (secretion of exosomes and microvesicles) mechanisms [32]. 
Extracellular vesicles are involved in the process of cell communication by transporting different types of molecules, such as proteins, mRNA and microRNA, and can act both in the tissues in which they originate and in distant sites [33].

The inclusion of miRNAs within apoptotic bodies, exosomes and microvesicles, as well as the association of secreted miRNAs with RNA-binding proteins (Argonaute 2) or complexes of lipoproteins (HDL) [34], make circulating miRNAs very stable and RNase-protected, even in difficult conditions (e.g., low/high pH environment) [35] (Figure 2).

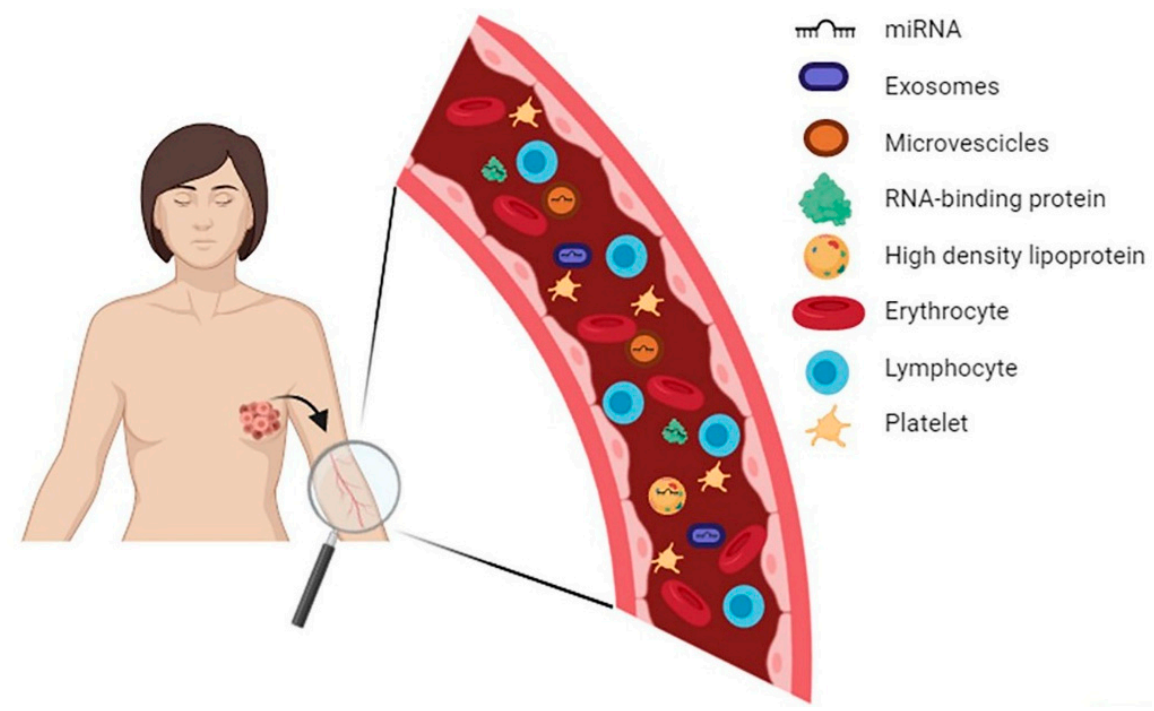

Figure 2. Schematic representation of miRNA release from tumor to bloodstream and compartmentalization of circulating miRNAs.

MiRNAs can be detected in plasma or serum via liquid biopsy by using specific and highly sensitive methods, such as real time quantitative reverse transcription-PCR [6,36], although the standardization of purification and analysis processes should be further improved [7,37].

Therefore, microRNAs produced by the tumor microenvironment, reflecting aberrant pathological processes, can pour into the bloodstream from which, due to the structure and nature that makes them resistant to RNase degradation, they can be easily recovered and analyzed, providing a source of characterizable and putatively suitable non-invasive disease biomarkers.

\section{Tissue MiRNAs in Breast Cancer Molecular Subtypes}

In the last decade, thanks to the advancement of knowledge on miRNAs in cancer pathogenesis and progression, an extensive amount of research has been focused on the identification and characterization of altered miRNAs' levels in BC. Several studies analyzed miRNA expression in BC tissues stratified in accordance with pathological features or subtypes. The dysregulation of different miRNAs was reported among the various BC molecular subtypes and their alteration was found to contribute to cancer progression and treatment response [38,39]. Furthermore, peculiar miRNA signatures, able to distinguish and differentiate BC subtypes, were identified [39]. For example, among the subtype-specific miRNAs, let-7c, let-7f and miR-10a were associated with Luminal A tumors; miR-18a, miR-135b, miR-93 and miR-155 were correlated with TNBC tumors; while miR-142-3p and miR-150 were associated with HER2+ tumors [40]. Moreover, the up-regulation of miR-342 was specifically observed in Luminal B cases [41].

Recently, Denkiewicz et al. [42] used bioinformatics and artificial intelligence to describe a wide BC molecular landscape. They integrated TCGA (The Cancer Genome Atlas) miRNA NGS dataset with clinical data to perform survival analysis, identify specific miRNAs for each BC subtype and analyze target genes and transcription factors targeting miRNAs as well. Among the 100 top 
microRNAs selected for each molecular subtype, they identified 44 miRNAs common to Luminal A, B, HER2-enriched and TN subgroups, and 12, 14, 9 and 15 miRNAs which were specific for each subtype. A set of 8 miRNAs with expression increases in stage II compared to I, was identified as well, with miR-10b-5p contributing to BC metastasis. The network analysis of miRNAs, target genes and transcription factors highlighted interesting interactions among them and relevant circuitries containing cancer key genes, such as TP53, BRCA1, Myc, ERS1, PI3K and pathways (e.g., KEGG breast cancer, apoptosis, p53, PI3K-Akt, MAPK, cell cycle).

Other researchers [43] performed small RNA sequencing of a set of 186 tumor samples subdivided by ER and HER2 expression arrangement (ER+/HER+, ER-/HER+, ER+/HER-, ER-/HER-). They described that miRNA expression levels can be facilitated to discriminate specific subtypes-miR-4728 specifically identified HER2-enriched tumors and miR99a/let-7c/miR-125b differentiated Luminal A from Luminal B subgroup.

Nama et al. [44] performed a study on the worst prognosis TN subtype and identified miR-138 hyperexpression with diagnostic and prognostic value. MiR-138 led cells to proliferation, inhibited apoptosis in vivo, and the tumor suppressor candidate TUSC2 was shown to be a direct target of miR-138. Amorim et al. [45] investigated miRNAs expression levels in 139 Luminal BC and identified a panel of four miRNAs (miR-30c-5p, 30b-5p, 182-5p, 200b-3p) as independent predictors of endocrine therapy benefits. MiR-182-5p and 200b-3p provided prognostic information about recurrence following endocrine therapy.

MiR-193a-3p downregulation was observed in HER2+ BC cells and tissues, and Tang et al. [46] demonstrated that miR-193a-3p methylation led to the progression of HER2+BC by targeting GRB7, that was frequently co-expressed with HER2 and correlated with a metastatic phonotype, ERK1/2, the phosphorylation of which was increased by GRB7 and FOXM1, a transcriptional regulator overexpressed in HER2+ cancers and activated by cyclin-cyclin dependent kinase and ERK-induced phosphorylation.

Overall, increasing evidence highlights the pivotal role and contribution of miRNAs in the progression and therapy response of different BC molecular subtypes and how the characterization of miRNA expression profiling could improve our understanding of BC heterogeneity.

\section{Circulating MiRNAs in Breast Cancer Molecular Subtypes}

Many studies analyzed circulating miRNAs with respect to BC molecular subtypes. Many of the microRNAs here described were already known to be dysregulated in cancer tissues and to play a role in tumor development and progression. Overall, cancer patients with different molecular features were compared in various ways, by often taking into consideration heterogeneous criteria for comparisons (e.g., HER2+ vs. HER2-; HER2+ vs. TNBC; Luminal vs. TNBC; Luminal vs. healthy controls; pre-therapy vs. post-therapy). The most recent literature is reported below and summarized in Table 1 to provide a clearer synopsis.

\subsection{Luminal Subtype}

Several studies focused on analyzing significant differentially expressed miRNAs in sera from Luminal BC patients vs. healthy controls, or from paired pre- vs. post-therapy samples, providing helpful information to be used for diagnosis and prognosis evaluation.

McDermott et al. [47] took advantage of innovative in silico methodologies to select miRNAs of potential interest and prospectively analyzed blood RNAs of 54 patients with Luminal-like A BC, compared to 56 controls. Data were analyzed by an artificial neural network and the levels of differentially expressed miRNAs were further validated by qRT-PCR. Four miRNAs (miR-29a, -181a, -223, -652) showed expression decrease in patients, and binary logistic regression corroborated that three of them (miR-29a, -181a, -652) may differentiate between affected women and healthy controls, providing elements for specific Luminal A tumor subtype detection. 
Pre- and post-adjuvant chemotherapy serum levels of miR-21, already described as highly expressed in BC, and miR-145, acting as a tumor suppressor and down-regulated in BC, were examined in 52 Luminal A BC patients [48]. The authors did not evidence any statistical difference, even though both miRNAs were described as dysregulated in several BC subtypes in other studies, reported below.

Table 1. Circulating microRNAs identified in the different breast cancer subtypes.

\begin{tabular}{|c|c|c|}
\hline MicroRNAs & Expression Level/Prognostic Value & Reference \\
\hline miR-29a, $-181 a,-223,-652$ & $\begin{array}{l}\text { Decreased level in Luminal A cases compared to } \\
\text { healthy controls }\end{array}$ & [47] \\
\hline miR-195 & $\begin{array}{l}\text { Decreased level in post-surgery Luminal A and B cases. } \\
\text { Significant increase in pre-operative Luminal B }\end{array}$ & [49] \\
\hline miR-155, -21 and $-10 b$ & Higher level in Luminal A cases compared to controls & \multirow[b]{2}{*}[50]{} \\
\hline let-7a & $\begin{array}{l}\text { Lower expression in Luminal A cases compared } \\
\text { to controls }\end{array}$ & \\
\hline $\operatorname{miR}-331$ & $\begin{array}{l}\text { Higher level in metastatic with respect to local Luminal } \\
\qquad \text { A cases and healthy controls }\end{array}$ & \multirow{2}{*}{ [51] } \\
\hline miR-195 & $\begin{array}{l}\text { Lower level in metastatic with respect to local Luminal A } \\
\text { cases and healthy controls }\end{array}$ & \\
\hline miR-21 & $\begin{array}{l}\text { Higher in non-metastatic HER2+ compared to } \\
\text { HER2- cases }\end{array}$ & \multirow{3}{*}{ [52] } \\
\hline $\mathrm{miR}-10 \mathrm{~b}$ & Higher in metastatic HER2+ compared to HER2- cases & \\
\hline miR-19a & $\begin{array}{l}\text { Favorable prognosis in patients with metastatic HER2+ } \\
\text { inflammatory BC }\end{array}$ & \\
\hline miR-183, -660, 29a, $-93,-378,-4281$ & Down-regulated in HER2+ vs. HER2- & \multirow{2}{*}{ [53] } \\
\hline $\operatorname{miR}-4283$ & Up-regulated in HER2+ vs. HER2- & \\
\hline miR-15a & $\begin{array}{l}\text { Lower level in HER2+ vs. HER2- cases of } \\
\text { inflammatory BC }\end{array}$ & [54] \\
\hline miR-18b, $-103,-107,-652$ & $\begin{array}{c}\text { Predictors of tumor relapse and OS in TNBC (highly } \\
\text { expressed in relapsing group) }\end{array}$ & [55] \\
\hline miR-720 & $\begin{array}{l}\text { Higher level in TNBC cases with invasive and } \\
\text { metastatic features }\end{array}$ & [56] \\
\hline miR-940 & Down-regulated and predictor of worst TNBC prognosis & [57] \\
\hline miR-34a & Down-regulated in TNBC cases vs. healthy controls & [58] \\
\hline miR-373 & Up-regulated in HER2- vs. HER2+ & \multirow{3}{*}{ [59] } \\
\hline miR-34a & Increased expression in HR- vs. HR+ & \\
\hline $\operatorname{miR}-17$ & Decreased expression in in HR+ vs. HR- & \\
\hline $\operatorname{miR}-373$ & $\begin{array}{l}\text { Higher in TNBC compared to Luminal BC and in HR- } \\
\text { compared to HR+ }\end{array}$ & {$[60]$} \\
\hline miRs-21, $-221,-210$, let-7a & $\begin{array}{l}\text { Higher expression in TNBC compared to triple } \\
\text { positive cases }\end{array}$ & \multirow[t]{2}{*}[61]{} \\
\hline miR-195, -145 & Lower in TNBC compared to triple positive cases & \\
\hline miR-21-5p, $-375,-205-5 p,-194-5 p$ & Up-regulated in $\mathrm{HR}+$ and TNBC recurrent patients & \multirow{2}{*}{ [62] } \\
\hline $\operatorname{miR}-382-5 p,-376 c-3 p,-411-5 p$ & Down-regulated in $\mathrm{HR}+$ and $\mathrm{TNBC}$ recurrent patients & \\
\hline
\end{tabular}


Table 1. Cont.

\begin{tabular}{|c|c|c|}
\hline MicroRNAs & Expression Level/Prognostic Value & Reference \\
\hline $\begin{array}{c}\text { miR-4270, }-1225-5 p,-188-5 p,-1202 \\
-4281,-1207-5 p,-642 b-3 p \\
-1290,-3141\end{array}$ & $\begin{array}{l}\text { Higher in HER2+ and TNBC with respect to } \\
\text { Luminal cases }\end{array}$ & [63] \\
\hline let-7a & Up-regulated in Luminal BC & \multirow{2}{*}{ [64] } \\
\hline miR-195 & Up-regulated in TNBC & \\
\hline miR-16, -21, -155, -195 & $\begin{array}{l}\text { Higher level in BC (regardless of the subtype) compared } \\
\text { to controls }\end{array}$ & {$[65]$} \\
\hline miR-200c & $\begin{array}{l}\text { Lower expression in TNBC vs. ER+/PR+, predicts } \\
\text { worst prognosis }\end{array}$ & {$[66]$} \\
\hline $\begin{array}{l}\operatorname{mir}-526 b,-6503,-487 b,-543,-627 \\
-3614,-18 b,-887,-30 e,-132,-4647\end{array}$ & Down-regulated in Luminal A cases vs. controls & \multirow{9}{*}{ [67] } \\
\hline $\begin{array}{l}\operatorname{mir}-122,-376 a,-196 a,-301 b,-23 a \\
-3065,-548 a h,-25,-335,-873\end{array}$ & Up-regulated in Luminal A cases vs. controls & \\
\hline $\begin{array}{l}\operatorname{mir}-873,-188,-146 a,-422 a \\
\quad-1283,-128-1\end{array}$ & Down-regulated in Luminal B cases vs. controls & \\
\hline mir-502, -548a, -548ar, -548ah, 203 & Up-regulated in Luminal B cases vs. controls & \\
\hline $\begin{array}{c}\operatorname{mir}-221,-582,-1302,-449 b,-888 \\
-378,-299,-887\end{array}$ & Down-regulated in Luminal B HER2+ cases vs. controls & \\
\hline $\operatorname{mir}-25,-379,-933,-615$ & Up-regulated in Luminal B HER2+ cases vs. controls & \\
\hline $\operatorname{mir}-584,-615,-1283$ & Down-regulated in HER2 enriched cases vs. controls & \\
\hline mir-548ar & Up-regulated in HER2 enriched cases vs. controls & \\
\hline $\operatorname{miR}-25-3 p$ & Up-regulated in TNBC cases vs. controls & \\
\hline miR-206 & Up-regulated in Luminal A and B cases & \multirow{2}{*}[68]{} \\
\hline miR-21 & Up-regulated in HER2+ and TNBC & \\
\hline $\operatorname{miR}-142-5 p,-320 a$ & Higher in Luminal A cases compared to controls & [69] \\
\hline
\end{tabular}

Abbreviations: +, positive; -, negative; $\mathrm{BC}$, breast cancer; $\mathrm{TNBC}$, triple negative breast cancer; OS, overall survival.

Cecener et al. [49] first analyzed miR-195 expression in 96 Luminal A and B BC tissues and then in pre- and post-operative blood samples from Turkish patients. They described miR-195 downregulation in $\mathrm{BC}$ with respect to normal adjacent tissues and significant down-regulation in post- vs. pre-operative samples. Moreover, a significant miR-195 blood increase was detected in Luminal B pre-operative specimens, suggesting that it might be considered as an early biomarker.

Pre- and post-surgery and treatment (chemo/radiotherapy) serum levels of the oncomiRs miR-21, miR-155, miR-10b, and the tumor suppressor Let-7a were analyzed in 30 Luminal A BC patients with respect to 10 unaffected controls [50]. MiR-155, -21 and -10b expression showed significant increase in BC; on the contrary, let-7a level decrease was detected in comparison to controls. Furthermore, serum levels of miR-21, $-155,-10 \mathrm{~b}$ decreased, whereas those of let-7a increased after surgery and therapy. The most significant differences were identified for miR-155. Overall, the results showed that Luminal A BC treatment led to a decrease in oncomiRs expression and an increase in contextual tumor suppressor miR, providing clinical information to be possibly used for monitoring the trend of the disease.

Another study [51] analyzed miRNA profiling in plasma specimens from age-matched patients with locally-confined or metastatic Luminal A BC and found significant higher miR-331 levels in metastatic patients with respect to local Luminal A and healthy controls. Conversely, miR-195 appeared hypo-expressed in metastatic patients and, used in combination to miR-331 levels, showed the ability to distinguish metastatic from Luminal A cancers. 


\subsection{HER2 Positive Subtype}

The role of significant differentially expressed circulating miRNAs in HER2+ molecular subtypes was investigated in several studies to evaluate their potential to distinguish BCs based on HER2 expression and to provide prognostic information.

MiR-21, $-10 \mathrm{~b},-19 \mathrm{a}$, all linked to BC cell proliferation, invasion and metastasis, were prospectively analyzed in a cohort of $113 \mathrm{BCs}$ for examining their putative use as biomarkers for more aggressive disease [52]. MiR-21 increased levels were observed for non-metastatic HER2+ with respect to HER2patients, whereas higher miR-10b expression was detected in metastatic HER2+ cancers compared to HER2-. Patients with metastatic inflammatory BC showed miR-19 level increase compared to metastatic non-inflammatory BC. The same miR was correlated with longer PFS (progression free survival) and OS (overall survival) in patients with metastatic HER2+ inflammatory BC, indicating that miR-19 can predict favorable prognosis for this specific BC subtype.

In a case-case study [53], the association between serum miRNA expression and cancers stratified for ER, PR, HER2 expression and lymph-node status was analyzed. Seven significant differentially expressed miRNAs (miR-183, -660, 29a, -93, -378, -4281, -4283) were identified in HER2+ vs. HER2cases, and 10 (miR-320b, -320d, -145, -320e, -1307, -767-3p, -125b, -605, -1825, -124) in lymph-node positive vs. negative patients, providing molecular markers associated to tumors with different features.

Hamdi et al. [54] analyzed circulating miRNA expression in inflammatory and non-inflammatory $B C$ and described lower miR-15a serum levels in the HER2+ subtype, offering a distinctive element for such a BC subgroup.

\subsection{TNBC Subtype}

TNBC corresponds to the worst prognosis BC subtype: for this reason, there is an urgent need to identify diagnostic, prognostic and predictive biomarkers. In this context, significant differentially expressed circulating miRNAs can be considered suitable and promising biomarkers.

Salhberg et al. [55] identified in sera from 60 primary TNBCs, and further validated in an additional independent cohort of 70 TNBCs, a panel of four miRNAs (miR-18b, -103,-107, and -652), as a predictor of tumor relapse and OS. The signature was highly expressed in the relapsing group, allowing patients' stratification and potentially guiding the choice of the most appropriate therapy.

The role of ADAM8, a protein known to be correlated with invasive and metastatic features in TNBC, was investigated in both in vitro and in vivo models by Das et al. [56]. ADAM8 was able to induce miR-720 expression by activating the ERK signaling cascade, and serum levels of miR-720 were found significantly higher in TNBC patients highly expressing ADAM8.

Another study showed that decreased serum levels of miR-940, a microRNA previously investigated in several types of cancer, were detected in $\mathrm{BC}$ patients with respect to controls and predicted worst prognosis in TNBC [57].

Finally, the role of the miR-34a, a tumor suppressor microRNA already described in different cancers, was examined by Li et al. [58] in TNBC patients compared with healthy controls. The authors detected miR-34a downregulation in patients, further demonstrating that miR-34a inhibition in TNBC cells enhanced tumor proliferation and glucose uptake by upregulating the glucose uptake and transporter 1 (GLUT1) gene, which plays a key role in the transport of glucose.

\subsection{Comparison among Different BC Subtypes}

In order to shed light on the $\mathrm{BC}$ heterogeneity, several studies were based on the comparison among different $\mathrm{BC}$ subtypes with the aim to identify circulating biomarkers able to distinguish $\mathrm{BC}$ subtypes and aggressiveness.

Eichelser et al. [59] analyzed after-surgery and before-chemotherapy serum levels of six microRNAs known to be involved in tumor development and metastasis spread (miR-10b, -17, -34a, -93, -155, and -373) in 120 patients with primary tumor, equally distributed in ER+/PR+, HER2+ and TNBC 
groups, 32 patients with metastasis and 40 healthy controls. MiR-34a, -93 and -373 were significantly higher in the primary BC group vs. controls, indicating their connection to cancer and potential early diagnostic value. In particular, for miR-373, an AUC (area under the curve) value of 0.879 ( $p=0.0001$ ), highlighting the relevant difference between the two groups considered, was reported. An increased miR-373 level was also observed in the HER2- patients, whereas different levels of miR-34a and miR-17 were shown by women with ER/PR negative and positive statuses, respectively. Moreover, miR-17 and miR-155 differentiated the primary BC group from the metastatic one, where decreased expression was observed. Altogether, the results suggested that such dysregulated miRNAs could be involved in the metastatic spread of BC subtypes.

Furthermore, the same research group examined pre-surgery and -chemotherapy blood levels of cell-free miR-101, -372 and -373 in 168 BC patients, 19 of which had benign disease, and 28 healthy controls. The same miRNAs were also examined in exosomes obtained from 50 patients and 12 healthy controls belonging to the same cohort. The study highlighted significantly different levels of miR-101 and miR-373 between BCs and benign samples, the higher expression of circulating exosomal miR-373 in TN compared to Luminal cases and in ER-/PR- cancers, compared to HR+ as well. Furthermore, miR-373 overexpression was able to induce ER down-regulation and apoptosis inhibition in the in vitro cell models, highlighting that miR-373 was correlated to a more aggressive BC phenotype [60].

Eighty-five paired tumor samples and sera were compared to healthy subjects and 15 benign fibroadenomas by Thakur et al. [61]. The significant hyper-expression of oncomiRs-21, -221, -210, and the hypo-expression of tumor suppressors miR-195 and -145, were observed in TN with respect to triple positive BCs, indicating a possible correlation with the aggressiveness of the disease. Furthermore, despite its tumor-suppressive role, let-7a was found up-regulated in TNBCs.

Huo et al. [62] identified a highly reliable miRNAs prognostic signature of seven miRNAs to distinguish BC patients with and without recurrence. Among them, miR-21-5p, -375, -205-5p, -194-5p appeared significantly up-regulated, whereas miR-382-5p, -376c-3p, -411-5p were down-regulated in recurrent patients. This signature was suitable for both HR+ and TNBCs.

A panel of 18 distinct up-regulated circulating miRNAs in $23 \mathrm{BC}$ individual patients with respect to nine healthy controls was identified by Hamam et al. [63]. Nine of those (miR-4270, -1225-5p, $-188-5 p,-1202,-4281,-1207-5 p,-642 b-3 p,-1290$ and -3141 ) were subsequently validated on 46 patients and 14 controls. The results demonstrated higher miRNA levels in stages I-III compared to stage IV, providing a putative distinctive element to be used for early diagnosis. Moreover, higher expression levels were detected in HER2+ and TN with respect to Luminal subtypes. Interestingly, this panel did not include some of the miRNAs most frequently hyper-expressed in breast tissues, leading us to hypothesize that circulating miRNAs could reflect not only the tumor microenvironment, but also the global homeostatic response to the disease.

Qattan et al. [64] analyzed the microRNA expression profiles in plasma from 36 patients with TNBC, 57 with Luminal BC, and from 34 disease-free controls. Data were also matched with RNAseq TCGA datasets. A panel of 18 miRNAs was isolated and 10 unique miRNAs were identified. Among them, let-7 and miR-195 were up-regulated in Luminal BCs and TNBCs, respectively. Conversely, data from TCGA showed a very low expression of both miRNAs in cancer tissues and high expression in adjacent non-cancer ones, probably indicating that tumor cells might selectively export miRNAs throughout the oncogenesis process.

The expression levels of circulating miR-16, miR-21 and miR-155, listed among the most hyper-expressed microRNAs in BC, and miR-195, considered as a BC-specific miRNA, were analyzed by Fan et al. [65] in 49 women with BC and 19 healthy controls with no history of BC. Serum levels of all four miRNAs were significantly increased in stage I BCs and in HER2-overexpressing, Luminal A/B and TN subtypes compared to controls, as further confirmed by ROC curve analysis, where high AUC values were obtained $(>0.8)$, suggesting a possible use as biomarkers for early diagnosis.

Niedźwiecki et al. [66] compared the serum expression of oncomiRs miR-21, miR-10b and of miR-200c, the downregulation of which was described as cell migration and metastasis promoter, 
in $46 \mathrm{TN}$ and ER+/PR+ BC patients. They found significantly lower miR-200c amounts in the TNBC group, highlighting the possible role of miR-200c levels as a biomarker predictor of worst prognosis and metastasis. Conversely, no significant differences were detected for miR-10b and -21 .

In a case-control study, Souza et al [67] identified a panel of 42 significant differentially expressed miRNAs in 54 (Luminal A, Luminal B, Luminal B HER2+, HER2-, TN) early stage BC patients-among them, 19, 8, 10, 4 of were significantly differentially expressed in Luminal A, Luminal B, Luminal B-HER2+, HER2 enriched types, respectively. Regarding TNBC, just miR-25-3p showed significant up-regulation and was able to distinguish the TN patients from heathy controls. Overall, the study demonstrated the possibility to obtain non-invasive molecular signatures for BC molecular subtypes classification.

The serum levels of miR-21, often overexpressed in BC, and miR-206, playing a role in the ER $\alpha$ regulatory loop, were examined in 75 BC patients stratified on ER, PR and HER2 statuses [68]. MiR-206 was found hyper-expressed in Luminal A and B subtypes, whereas an miR-21 increase was observed in HER2+ and TNBCs. Furthermore, the expression of the latter microRNA was negatively associated with ER and PR expression level, and positively with HER2 and malignancy. Conversely, an opposite behavior was described for miR-206. Therefore, miR-21 and -206 correlated with HR and HER2 expression and could distinguish Luminal from the worst prognosis HER2+/TNBC subtypes.

Finally, Ozawa et al. [69] analyzed miRNAs extracted from extracellular vesicles of 16 Luminal A and 15 TNBC patients compared to the controls. They selected four miRNAs (miR-142-5p, -150-5p, $-320 a,-4433 b-5 p$ ) and demonstrated that miR-142-5p, miR-320a, and miR-4433b-5p were able to distinguish $B C$ patients from healthy individuals with $93 \%$ sensitivity and $68 \%$ specificity. Furthermore, the association of miR-142-5p and miR-320a discriminated Luminal A BC from the control with 100\% sensitivity and $93 \%$ specificity, whereas decreased levels of miR-142-5p and miR-150-5p were correlated with grade III tumors and the lower expression of miR-142-5p and miR-320a with higher tumor size.

Overall, the above-reported results, arising from studies based on the analysis and comparison of breast cancers subtypes, often differentially stratified and arranged, clearly demonstrate that circulating miRNAs levels can provide interesting data to better define the biological heterogeneity of $\mathrm{BC}$ and support diagnostic, prognostic and predictive clinical evaluation.

\section{BC Molecular Subtypes: Differentially Expressed MiRNAs in Response to Therapies}

It is known that different BC subtypes can differently respond to therapies. For example, the Luminal A subtype is responsive to endocrine therapy-conversely, it is less sensitive to chemotherapy. Furthermore, thanks to the generation of targeted drugs, over the last few decades, trastuzumab and lapatinib have greatly improved prognosis of HER2+ BCs. However, a percentage of initially responding patients can later develop resistance to therapeutic treatments. Several studies were aimed at investigating the significance of differentially expressed circulating miRNAs in response to therapies (Table 2).

A cohort of 68 Luminal A patients subjected to neoadjuvant epirubicin plus paclitaxel chemotherapy was analyzed by Li et al. [70]. Among eight serum differentially expressed miRNAs, they described miR-19a and miR-205, which were hyper-expressed in the resistant group, as significantly able to predict the sensitivity of Luminal A BCs to this therapeutic regimen, providing non-invasive biomarkers for better defining in advance the expected response.

Circulating levels of miR-21, -210 and -373 were assayed in 127 HER2+ patients pre- and post-neoadjuvant therapy (chemotherapy combined to trastuzumab/lapatinib) [71]. Significantly higher miR-21, -210 and -373 levels were detected before and after therapy in BC patients compared to healthy controls. MiR-21, -210 and -373 increase was further observed in patients after therapy. The expression of miR-21 before and after therapy was correlated with OS, regardless of the type of anti-HER2 treatment, and higher circulating miR-373 expression was observed in advanced stage $\mathrm{BC}$, highlighting the potential role of those microRNAs in prognosis assessment. On the contrary, the association between serum microRNA and pathological response was not evidenced. 
Table 2. Role of circulating microRNAs in response to therapies of breast cancer subtypes.

\begin{tabular}{|c|c|c|}
\hline MicroRNAs & Expression Level/Prognostic Value & Reference \\
\hline $\operatorname{miR}-19 a,-205$ & $\begin{array}{l}\text { Up-regulated in chemotherapy resistant compared to } \\
\text { sensitive Luminal A cases }\end{array}$ & {$[70]$} \\
\hline $\operatorname{miR}-21,-210,-373$ & $\begin{array}{c}\text { Higher in HER2+ cases, before and after neoadjuvant } \\
\text { therapy (chemotherapy combined to } \\
\text { trastuzumab/lapatinib), compared to controls }\end{array}$ & [71] \\
\hline $\begin{array}{c}\operatorname{miR}-720,-4716-5 p,-17-3 p,-451 a \\
-16-5 p,-451 b,-940,-10 b-3 p \\
-30 b-3 p,-4310,-494,-22-3 p,-29 a-5 p\end{array}$ & $\begin{array}{l}\text { Differentially expressed in metastatic HER2+ cases in } \\
\text { relation to trastuzumab response }\end{array}$ & \multirow{2}{*}{ [72] } \\
\hline $\operatorname{miR}-940,-451 a,-16-5 p,-17-3 p$ & $\begin{array}{l}\text { Predictors of trastuzumab sensitivity in metastatic } \\
\text { HER2+ cases }\end{array}$ & \\
\hline miR-21 & $\begin{array}{c}\text { Decreased level in HER+ cases after trastuzumab } \\
\text { treatment: prognostic and predictive factor of } \\
\text { trastuzumab response }\end{array}$ & [73] \\
\hline miR-21, -105 & $\begin{array}{l}\text { Increased level in pre-neoadjuvant chemotherapy } \\
\text { metastatic BC cases compared to non-metastatic cases } \\
\text { and controls }\end{array}$ & [74] \\
\hline $\operatorname{miR}-200 b,-135 b,-29 a$ & Up-regulated in HER2 + trastuzumab-resistant cases & \multirow{2}{*}{ [75] } \\
\hline $\operatorname{miR}-224$ & Down-regulated in HER2+ trastuzumab-resistant cases & \\
\hline $\operatorname{miR}-21$ & $\begin{array}{l}\text { Predictor of therapy response (neoadjuvant } \\
\text { chemotherapy plus trastuzumab) in HER2+ cases }\end{array}$ & [76] \\
\hline $\operatorname{miR}-17,-19 b,-30 b$ & $\begin{array}{l}\text { Predictors of response to neoadjuvant chemotherapy in } \\
\text { TNBC cases }\end{array}$ & [77] \\
\hline miR-21, -195. -145 & $\begin{array}{l}\text { Predictors of response to neoadjuvant chemotherapy in } \\
\text { Luminal BC cases }\end{array}$ & [78] \\
\hline
\end{tabular}

Abbreviations: +, positive; -, negative; $\mathrm{BC}$, breast cancer; $\mathrm{TNBC}$, triple negative breast cancer.

In a recent article, Li et al [72] identified a panel of 13 serum miRNAs (miR-720, -4716-5p, -17-3p, $-451 a,-16-5 p,-451 b,-940,-10 b-3 p,-30 b-3 p,-4310,-494,-22-3 p,-29 a-5 p)$ differentially expressed in metastatic HER2+ women who exhibited distinct responses to trastuzumab. Among them, four microRNAs (miR-940, -451a, -16-5p, -17-3p), specifically targeting molecules involved in pathway conferring anti-HER2 resistance of BC cells (SRC, PTEN, IGFR1), were used to predict sensitivity to trastuzumab.

The oncomiR 21 was identified as a prognostic and predictive factor for the response to trastuzumab in 20 HER2+ metastatic BCs [73]. MiR-21 level decrease, also correlated to time to progression, was observed after trastuzumab treatment, with higher difference in responders.

Rodríguez-Martínez et al. [74] prospectively analyzed 53 women with localized BC who underwent neoadjuvant chemotherapy. Afterwards, among them, six developed metastatic disease. The authors reported pre-therapy serum exosomal miRNA-21 and -105 increases in metastatic patients with respect to non-metastatic women and controls. Moreover, higher miR-222 expression levels were detected in basal-like and in Luminal B vs. A tumors and correlated to progesterone receptor status and Ki67. Under treatment, the levels of miR-21 were correlated to tumor size and, in an inverse manner, to Ki67. Global miRNA-21, -222, -155 high levels were significantly linked to circulating cancer cells into the blood.

Microarray analysis was performed to discriminate trastuzumab sensitive and resistant cell lines and isolate differentially-expressed miRNAs [75]. Among the most interesting, miR-200b, $-135 b,-29 a$, -224 were validated and showed differential expression on sera from HER2+ patients (200b, 135b, 29a up-regulated; 224 down-regulated in trastuzumab-resistant patients), demonstrating a correlation with response to therapy. 
Liu et al. [76] examined the relationship between serum miRNAs and the aresponse of HER2+ patients treated with neoadjuvant chemotherapy plus trastuzumab. MiR-21 decreased levels were observed throughout treatment administration, demonstrating a significant correlation with prognosis and clinical response.

Circulating miRNAs as putative biomarkers of the response to neoadjuvant therapy of TNBCs were examined by Ritter et al. [77]. After analyzing the expression levels of miR-7, $-9,-15 a,-17,-18 a,-19 b$, $-21,-30 b,-222$ and $-320 c$ in triple positive and TNBC cell models treated with several chemotherapeutic drugs, they described a putative association between miR-17, $-19 \mathrm{~b}$ and $-30 \mathrm{~b}$ expression serum levels and neoadjuvant chemotherapy-driven complete clinical response, highlighting the importance of these miRNAs in monitoring therapeutic outcome. The decreased expressions of miR-21 and miR-195 were observed in patients who responded to neoadjuvant chemotherapy with respect to non-responders. MiR-21 was described as a treatment predictor and, associated with miR-145, was found significantly reduced in responder Luminal cases [78].

\section{Conclusions}

MicroRNAs have emerged as key regulators of BC pathogenesis, progression and treatment response. Recently, some studies have focused on analyzing dysregulated BC miRNAs in plasma/serum to identify novel groups of biomarkers for predicting prognosis and, more efficiently, therapy response, also with reference to specific BC subtypes.

Several circulating miRNAs were described as differentially expressed in BC molecular subgroups, providing elements to be used not only to examine the biological heterogeneity of breast tumors in more depth, but also to stratify patients and provide a decisional support for clinical management. To date, the availability of sensitive and high-performance technologies, such as qRT-PCR or small-RNA NGS sequencing, offers great opportunity to specifically and sensitively assess circulating miRNAs' expression levels, although the complexity of serum/plasma specimens still requires the improvement and standardization of analytical procedures to ameliorate the generation of data suitable for clinical utility. In addition, more extensive serum/plasma miRnome profiling could be beneficial and helpful to highlight significant differences for isolating groups of multiple and associated putative biomarkers to be further validated. Furthermore, to examine in depth mechanisms related to BC subtypes and expand the knowledge of the molecular landscape, it would be interesting and promising to characterize genes targeted by differentially-expressed miRNAs as well.

The studies here reviewed were based on cohorts of patients often enrolled on the basis of different clinical/therapeutic features and, in certain situations, showed conflicting results. However, among the miRNAs here discussed, some deserve interest and could be subjected to deeper examination. For example, it would be relevant to further analyze miR-21, $-10 \mathrm{~b},-378,-373,-188$, the expressions of which seems to provide more coherent predictive and/or prognostic information, especially for HER2+ BCs. All the above-mentioned microRNAs were described in tumorigenesis. MiR-21 is one of the most well-studied microRNAs in cancer. It targets genes (e.g., PTEN, SPRY2, TIMP3, RECK) involved in the negative regulation of cell proliferation, apoptosis, metastasis and invasion pathways, such as PI3K/AKT, ERK/MAPK, and VEGFA. Furthermore, miR-21 is considered as a diagnostic, prognostic and predictive biomarker in several tumor types, including BC [79-81]. In the same way, miR-10b was described as an oncomiR in BC by targeting tumor suppressive genes (e.g., PDCD4, PTEN, TPM1), thus promoting proliferation, invasion and metastasis, and predicting the worst $\mathrm{BC}$ prognosis [82]. MiR-378 is known to suppress migration and invasion in BC cells and mouse models by targeting Runx1, one of the most mutated genes in BC [83], and Yin et al. [84] showed miR-378 up-regulation in BC patients vs. controls. MiR-373 was shown to enhance cell migration by suppressing ITGA2, the lack of which plays a relevant role in metastasis spread [85]; moreover, it was found hyper-expressed in TNBC [86]. Multiple roles were reported for miR-188, which negatively regulated cell proliferation and migration by targeting IL6ST [87] or enhanced apoptosis by suppressing the anti-apoptosis and pro-survival Rap2c [88]. 
In conclusion, further studies focused on the analysis of large, well-defined and stratified cohorts of patients are needed to validate the promising results already obtained and to identify novel miRNAs to be used as non-invasive prognostic and predictive biomarkers in BC subtypes. This will provide advantageous complementary knowledge not only about $\mathrm{BC}$ genetic arrangements and molecular features, thus shedding light on BC biological heterogeneity, but also on their use in the field of personalized medicine for optimizing diagnostic and prognostic clinical evaluation, as well as therapeutic options.

Author Contributions: Conceptualization, V.Z., A.T, and E.A.; Writing-Original Draft Preparation, V.Z., C.C. (Chiara Compagnoni), and R.C.; Bibliographic Information, K.C., T.S., C.F. and C.C. (Carlo Capalbo); Writing-Review and Editing, F.Z., A.T., and E.A. All authors have read and agreed to the published version of the manuscript.

Funding: This research was funded by MIUR-FIRB, grant n. RBAP10A9H9 to Edoardo Alesse.

Conflicts of Interest: The authors declare no conflict of interest.

\section{References}

1. Bray, F.; Ferlay, J.; Soerjomataram, I.; Siegel, R.L.; Torre, L.A.; Jemal, A. Global cancer statistics 2018: GLOBOCAN estimates of incidence and mortality worldwide for 36 cancers in 185 countries. CA Cancer J. Clin. 2018, 68, 394-424. [CrossRef] [PubMed]

2. Bertoli, G.; Cava, C.; Castiglioni, I. MicroRNAs: New Biomarkers for Diagnosis, Prognosis, Therapy Prediction and Therapeutic Tools for Breast Cancer. Theranostics 2015, 5, 1122-1143. [CrossRef] [PubMed]

3. Russnes, H.G.; Lingjærde, O.C.; Børresen-Dale, A.L.; Caldas, C. Breast Cancer Molecular Stratification: From Intrinsic Subtypes to Integrative Clusters. Am. J. Pathol. 2017, 187, 2152-2162. [CrossRef]

4. Rupaimoole, R.; Slack, F.J. MicroRNA therapeutics: Towards a new era for the management of cancer and other diseases. Nat. Rev. Drug Discov. 2017, 16, 203-222. [CrossRef] [PubMed]

5. Valentini, V.; Zelli, V.; Gaggiano, E.; Silvestri, V.; Rizzolo, P.; Bucalo, A.; Calvieri, S.; Grassi, S.; Frascione, P.; Donati, P.; et al. MiRNAs as Potential Prognostic Biomarkers for Metastasis in Thin and Thick Primary Cutaneous Melanomas. Anticancer Res. 2019, 39, 4085-4093. [CrossRef] [PubMed]

6. Mitchell, P.S.; Parkin, R.K.; Kroh, E.M.; Fritz, B.R.; Wyman, S.K.; Pogosova-Agadjanyan, E.L.; Peterson, A.; Noteboom, J.; O'Briant, K.C.; Allen, A.; et al. Circulating microRNAs as stable blood-based markers for cancer detection. Proc. Natl. Acad. Sci. USA 2008, 105, 10513-10518. [CrossRef]

7. Wang, H.; Peng, R.; Wang, J.; Qin, Z.; Xue, L. Circulating microRNAs as potential cancer biomarkers: The advantage and disadvantage. Clin. Epigenetics 2018, 10, 59. [CrossRef]

8. Petrovic, N.; Davidovic, R.; Bajic, V.; Obradovic, M.; Isenovic, R.E. MicroRNA in breast cancer: The association with BRCA1/2. Cancer Biomark 2017, 19, 119-128. [CrossRef]

9. Hamam, R.; Hamam, D.; Alsaleh, K.A.; Kassem, M.; Zaher, W.; Alfayez, M.; Aldahmash, A.; Alajez, N.M. Circulating microRNAs in breast cancer: Novel diagnostic and prognostic biomarkers. Cell Death Dis. 2017, 8, e3045. [CrossRef]

10. Yangm, Z.; Liu, Z. The Emerging Role of MicroRNAs in Breast Cancer. J. Oncol. 2020, 2020, 9160905.

11. Viale, G. The current state of breast cancer classification. Ann. Oncol. 2012, 23, 207-210. [CrossRef] [PubMed]

12. Harbeck, N.; Gnant, M. Breast cancer. Lancet 2017, 389, 1134-1150. [CrossRef]

13. Perou, C.M.; Sorlie, T.; Eisen, M.B.; van de Rijn, M.; Jeffrey, S.S.; Rees, C.A.; Pollack, J.R.; Ross, D.T.; Johnsen, H.; Akslen, L.A.; et al. Molecular portraits of human breast tumours. Nature 2000, 406, 747-752. [CrossRef] [PubMed]

14. van't Veer, L.J.; Dai, H.; van de Vijver, M.J.; He, Y.D.; Hart, A.A.; Mao, M.; Peterse, H.L.; van der Kooy, K.; Marton, M.J.; Witteveen, A.T.; et al. Gene expression profiling predicts clinical outcome of breast cancer. Nature 2002, 415, 530-536. [CrossRef]

15. Sorlie, T.; Tibshirani, R.; Parker, J.; Hastie, T.; Marron, J.S.; Nobel, A.; Deng, S.; Johnsen, H.; Pesich, R.; Geisler, S.; et al. Repeated observation of breast tumor subtypes in independent gene expression data sets. Proc. Natl. Acad. Sci. USA 2003, 100, 8418-8423. [CrossRef] 
16. Prat, A.; Parker, J.S.; Karginova, O.; Fan, C.; Livasy, C.; Herschkowitz, J.I.; He, X.; Perou, C.M. Phenotypic and molecular characterization of the claudin-low intrinsic subtype of breast cancer. Breast Cancer Res. 2010, 12, R68. [CrossRef]

17. Sisti, J.S.; Collins, L.C.; Beck, A.H.; Tamimi, R.M.; Rosner, B.A.; Eliassen, A.H. Reproductive risk factors in relation to molecular subtypes of breast cancer: Results from the nurses' health studies. Int. J. Cancer 2016, 138, 2346-2356. [CrossRef]

18. Hicks, J.; Krasnitz, A.; Lakshmi, B.; Navin, N.E.; Riggs, M.; Leibu, E.; Esposito, D.; Alexander, J.; Troge, J.; Grubor, V.; et al. Novel patterns of genome rearrangement and their association with survival in breast cancer. Genome Res. 2006, 16, 1465-1479. [CrossRef]

19. Chin, K.; DeVries, S.; Fridlyand, J.; Spellman, P.T.; Roydasgupta, R.; Kuo, W.-L.; Lapuk, A.; Neve, R.M.; Qian, Z.; Ryder, T.; et al. Genomic and transcriptional aberrations linked to breast cancer pathophysiologies. Cancer Cell 2006, 10, 529-541. [CrossRef]

20. Curtis, C.; Shah, S.P.; Chin, S.-F.; Turashvili, G.; Rueda, O.M.; Dunning, M.J.; Speed, D.; Lynch, A.G.; Samarajiwa, S.; Yuan, Y.; et al. The genomic and transcriptomic architecture of 2000 breast tumours reveals novel subgroups. Nature 2012, 486, 346-352. [CrossRef]

21. Natrajan, R.; Weigelt, B.; Mackay, A.; Geyer, F.C.; Grigoriadis, A.; Tan, D.S.P.; Jones, C.; Lord, C.J.; Vatcheva, R.; Rodriguez-Pinilla, S.M.; et al. An integrative genomic and transcriptomic analysis reveals molecular pathways and networks regulated by copy number aberrations in basal-like, HER2 and Luminal cancers. Breast Cancer Res. Treat 2010, 121, 575-589. [CrossRef] [PubMed]

22. Bergamaschi, A.; Hjortland, G.O.; Triulzi, T.; Sørlie, T.; Johnsen, H.; Ree, A.H.; Russnes, H.G.; Tronnes, S.; Mælandsmo, G.M.; Fodstad, O.; et al. Molecular profiling and characterization of Luminal-like and basal-like in vivo breast cancer xenograft models. Mol. Oncol. 2009, 3, 469-482. [CrossRef] [PubMed]

23. Sparano, J.A.; Gray, R.J.; Makower, D.F.; Pritchard, K.I.; Albain, K.S.; Hayes, D.F.; Geyer, C.E., Jr.; Dees, E.C.; Perez, E.A.; Olson, J.A., Jr.; et al. Prospective Validation of a 21-Gene Expression Assay in Breast Cancer. N. Engl. J. Med. 2015, 373, 2005-2014. [CrossRef] [PubMed]

24. Sparano, J.A.; Gray, R.J.; Ravdin, P.M.; Makower, D.F.; Pritchard, K.I.; Albain, K.S.; Hayes, D.F.; Geyer, C.E., Jr.; Dees, E.C.; Goetz, M.P.; et al. Clinical and Genomic Risk to Guide the Use of Adjuvant Therapy for Breast Cancer. N. Engl. J. Med. 2019, 380, 2395-2405. [CrossRef] [PubMed]

25. Cardoso, F.; van't Veer, L.J.; Bogaerts, J.; Slaets, L.; Viale, G.; Delaloge, S.; Pierga, J.Y.; Brain, E.; Causeret, S.; DeLorenzi, M.; et al. 70-Gene Signature as an Aid to Treatment Decisions in Early-Stage Breast Cancer. N. Engl. J. Med. 2016, 375, 717-729. [CrossRef]

26. Aalders, K.C.; Kuijer, A.; Straver, M.E.; Slaets, L.; Litiere, S.; Viale, G.; Van't Veer, L.J.; Glas, A.M.; Delorenzi, M.; van Dalen, T.; et al. Characterisation of multifocal breast cancer using the 70-gene signature in clinical low-risk patients enrolled in the EORTC 10041/BIG 03-04 MINDACT trial. Eur. J. Cancer 2017, 79, 98-105. [CrossRef]

27. Bartel, D.P. MicroRNAs: Genomics, biogenesis, mechanisms, and function. Cell 2004, 116, 281-297. [CrossRef]

28. Di Leva, G.; Garofalo, M.; Croce, C.M. MicroRNAs in cancer. Annu. Rev. Phatol. 2014, 9, 287-314. [CrossRef]

29. Nakahara, K.; Carthew, R.W. Expanding roles for miRNAs and siRNAs in cell regulation. Curr. Opin. Cell. Biol. 2004, 16, 127-133. [CrossRef]

30. Calin, G.A.; Croce, C.M. MicroRNA signatures in human cancers. Nat. Rev. Cancer 2006, 6, 857-866. [CrossRef]

31. Ichimura, A.; Ruike, Y.; Terasawa, K.; Tsujimoto, G. MicroRNAs and regulation of cell signaling. FEBS J. 2011, 278, 1610-1618. [CrossRef] [PubMed]

32. Hunter, M.P.; Ismail, N.; Zhang, X.; Aguda, B.D.; Lee, E.J.; Yu, L.; Xiao, T.; Schafer, J.; Ting Lee, M.-L.; Schmittgen, T.D.; et al. Detection of microRNA expression in human peripheral blood microvesicles. PLoS ONE 2008, 3, e3694. [CrossRef] [PubMed]

33. Tessitore, A.; Cicciarelli, G.; Mastroiaco, V.; Vecchio, F.D.; Capece, D.; Verzella, D.; Fischietti, M.; Vecchiotti, D.; Zazzeroni, F.; Alesse, E. Therapeutic Use of MicroRNAs in Cancer. Anticancer Agents Med. Chem. 2016, 16, 7-19. [CrossRef] [PubMed]

34. Arroyo, J.D.; Chevillet, J.R.; Kroh, E.M.; Ruf, I.K.; Pritchard, C.C.; Gibson, D.F.; Mitchell, P.S.; Bennett, C.F.; Pogosova-Agadjanyan, E.L.; Stirewalt, D.L.; et al. Argonaute2 complexes carry a population of circulating microRNAs independent of vesicles in human plasma. Proc. Natl. Acad. Sci. USA 2011, 108, 5003-5008. [CrossRef] 
35. Creemers, E.E.; Tijsen, A.J.; Pinto, Y.M. Circulating microRNA novel biomarkers and extracellular communicators in cardiovascular disease? Circ. Res. 2012, 110, 483-495. [CrossRef]

36. Kroh, E.M.; Parkin, R.K.; Mitchell, P.S.; Tewari, M. Analysis of circulating microRNA biomarkers in plasma and serum using quantitative reverse transcription-PCR (qRT-PCR). Methods 2010, 50, 298-301. [CrossRef]

37. Cui, M.; Wang, H.; Yao, X.; Zhang, D.; Xie, Y.; Cui, R.; Zhang, X. Circulating MicroRNAs in Cancer: Potential and Challenge. Front Genet. 2019, 10, 626. [CrossRef]

38. Dastmalchi, N.; Safaralizadeh, R.; Baradaran, B.; Hosseinpourfeizi, M.; Baghbanzadeh, A. An update review of deregulated tumor suppressive microRNAs and their contribution in various molecular subtypes of breast cancer. Gene 2020, 729, 144301. [CrossRef]

39. Kurozumi, S.; Yamaguchi, Y.; Kurosumi, M.; Ohira, M.; Matsumoto, H.; Horiguchi, J. Recent trends in microRNA research into breast cancer with particular focus on the associations between microRNAs and intrinsic subtypes. J. Hum. Genet. 2017, 62, 15-24. [CrossRef]

40. van Schooneveld, E.; Wildiers, H.; Vergote, I.; Vermeulen, P.B.; Dirix, L.Y.; Van Laere, S.J. Dysregulation of microRNAs in breast cancer and their potential role as prognostic and predictive biomarkers in patient management. Breast Cancer Res. 2015, 17, 21. [CrossRef]

41. Lowery, A.J.; Miller, N.; Devaney, A.; McNeill, R.E.; Davoren, P.A.; Lemetre, C.; Benes, V.; Schmidt, S.; Blake, J.; Ball, G.; et al. MicroRNA signatures predict oestrogen receptor, progesterone receptor and HER2/neu receptor status in breast cancer. Breast Cancer Res. 2009, 11, R27. [CrossRef] [PubMed]

42. Denkiewicz, M.; Saha, I.; Rakshit, S.; Sarkar, J.P.; Plewczynski, D. Identification of Breast Cancer Subtype Specific MicroRNAs Using Survival Analysis to Find Their Role in Transcriptomic Regulation. Front Genet. 2019, 10, 1047. [CrossRef] [PubMed]

43. Søkilde, R.; Persson, H.; Ehinger, A.; Pirona, A.C.; Fernö, M.; Hegardt, C.; Larsson, C.; Loman, N.; Malmberg, M.; Rydén, L.; et al. Refinement of breast cancer molecular classification by miRNA expression profiles. BMC Genomics 2019, 20, 503. [CrossRef] [PubMed]

44. Nama, S.; Muhuri, M.; Di Pascale, F.; Quah, S.; Aswad, L.; Fullwood, M.; Sampath, P. MicroRNA-138 is a Prognostic Biomarker for Triple-Negative Breast Cancer and Promotes Tumorigenesis via TUSC2 repression. Sci. Rep. 2019, 9, 12718. [CrossRef] [PubMed]

45. Amorim, M.; Lobo, J.; Fontes-Sousa, M.; Estevão-Pereira, H.; Salta, S.; Lopes, P.; Coimbra, N.; Antunes, L.; Palma de Sousa, S.; Henrique, R.; et al. Predictive and Prognostic Value of Selected MicroRNAs in Luminal Breast Cancer. Front Genet. 2019, 10, 815. [CrossRef]

46. Tang, Y.; Yang, S.; Wang, M.; Liu, D.; Liu, Y.; Zhang, Y.; Zhang, Q. Epigenetically altered miR-193a-3p promotes HER2 positive breast cancer aggressiveness by targeting GRB7. Int. J. Mol. Med. 2019, 43, 2352-2360. [CrossRef]

47. McDermott, A.M.; Miller, N.; Wall, D.; Martyn, L.M.; Ball, G.; Sweeney, K.J.; Kerin, M.J. Identification and validation of oncologic miRNA biomarkers for Luminal A-like breast cancer. PLoS ONE 2014, 9, e87032. [CrossRef]

48. Yoruker, E.E.; Aydoğan, F.; Gezer, U.; Saip, P.; Dalay, N. Analysis of circulating microRNAs during adjuvant chemotherapy in patients with Luminal A breast cancer. Mol. Clin. Oncol. 2015, 3, 954-958. [CrossRef]

49. Cecene, G.; Ak, S.; Eskiler, G.G.; Demirdogen, E.; Erturk, E.; Gokgoz, S.; Polatkan, V.; Egeli, U.; Tunca, B.; Tezcan, G.; et al. Circulating miR-195 as a Therapeutic Biomarker in Turkish Breast Cancer Patients. Asian Pac. J. Cancer Prev. 2016, 17, 4241-4246.

50. Khalighfard, S.; Alizadeh, A.M.; Irani, S.; Omranipour, R. Plasma miR-21, miR-155, miR-10b, and Let-7a as the potential biomarkers for the monitoring of breast cancer patients. Sci. Rep. 2018, 8, 17981. [CrossRef]

51. McAnena, P.; Tanriverdi, K.; Curran, C.; Gilligan, K.; Freedman, J.E.; Brown, J.A.L.; Kerin, M.J. Circulating microRNAs miR-331 and miR-195 differentiate local Luminal a from metastatic breast cancer. BMC Cancer 2019, 19, 436. [CrossRef] [PubMed]

52. Anfossi, S.; Giordano, A.; Gao, H.; Cohen, E.N.; Tin, S.; Wu, Q.; Garza, R.J.; Debeb, B.G.; Alvarez, R.H.; Valero, V.; et al. High serum miR-19a levels are associated with inflammatory breast cancer and are predictive of favorable clinical outcome in patients with metastatic HER2+ inflammatory breast cancer. PLoS ONE 2014, 9, e83113. [CrossRef] [PubMed]

53. Godfrey, A.C.; Xu, Z.; Weinberg, C.R.; Getts, R.C.; Wade, P.A.; DeRoo, L.A.; Sandler, D.P.; Taylor, J.A. Serum microRNA expression as an early marker for breast cancer risk in prospectively collected samples from the Sister Study cohort. Breast Cancer Res. 2013, 15, R42. [CrossRef] [PubMed] 
54. Hamdi, K.; Blancato, J.; Goerlitz, D.; Islam, M.; Neili, B.; Abidi, A.; Gat, A.; Ayed, F.B.; Chivi, S.; Loffredo, C.; et al. Circulating Cell-free miRNA Expression and its Association with Clinicopathologic Features in Inflammatory and Non- Inflammatory Breast Cancer. Asian Pac. J. Cancer Prev. 2016, 17, 1801-1810. [CrossRef]

55. Sahlberg, K.K.; Bottai, G.; Naume, B.; Burwinkel, B.; Calin, G.A.; Børresen, A.A.; Santarpia, L.A. Serum microRNA Signature Predicts Tumor Relapse and Survival in Triple-Negative Breast Cancer Patients. Clin. Cancer Res. 2015, 21, 1207-1214. [CrossRef]

56. Das, S.G.; Romagnoli, M.; Mineva, N.D.; Barillé-Nion, S.; Jézéquel, P.; Campone, M.; Sonenshein, G.E. miR-720 is a downstream target of an ADAM8-induced ERK signaling cascade that promotes the migratory and invasive phenotype of triple-negative breast cancer cells. Breast Cancer Res. 2016, 18, 40. [CrossRef]

57. Liu, W.; Xu, Y.; Guan, H.; Meng, H. Clinical potential of miR-940 as a diagnostic and prognostic biomarker in breast cancer patients. Cancer Biomark 2018, 22, 487-493. [CrossRef]

58. Li, Z.; Gong, X.; Zhang, W.; Zhang, J.; Ding, L.; Li, H.; Tu, D.; Tang, J. Inhibition of miRNA-34a promotes triple negative cancer cell proliferation by promoting glucose uptake. Exp. Ther. Med. 2019, 18, 3936-3942. [CrossRef]

59. Eichelser, C.; Flesch-Janys, D.; Chang-Claude, J.; Pantel, K.; Schwarzenbach, H. Deregulated serum concentrations of circulating cell-free microRNAs miR-17, miR-34a, miR-155, and miR-373 in human breast cancer development and progression. Clin. Chem. 2013, 59, 1489-1496. [CrossRef]

60. Eichelser, C.; Stückrath, I.; Müller, V.; Milde-Langosch, K.; Wikman, H.; Pantel, K.; Schwarzenbach, H. Increased serum levels of circulating exosomal microRNA-373 in receptor-negative breast cancer patients. Oncotarget 2014, 5, 9650-9663. [CrossRef]

61. Thakur, S.; Grover, R.K.; Gupta, S.; Yadav, A.K.; Das, B.C. Identification of Specific miRNA Signature in Paired Sera and Tissue Samples of Indian Women with Triple Negative Breast Cancer. PLoS ONE 2016, 11, e0158946. [CrossRef] [PubMed]

62. Huo, D.; Clayton, W.M.; Yoshimatsu, T.F.; Chen, J.; Olopade, O.I. Identification of a circulating microRNA signature to distinguish recurrence in breast cancer patients. Oncotarget 2016, 7, 55231-55248. [CrossRef] [PubMed]

63. Hamam, R.; Ali, A.M.; Alsaleh, K.A.; Kassem, M.; Alfayez, M.; Aldahmash, A.; Alajez, N.M. microRNA expression profiling on individual breast cancer patients identifies novel panel of circulating microRNA for early detection. Sci. Rep. 2016, 6, 25997. [CrossRef] [PubMed]

64. Qattan, A.; Intabli, H.; Alkhayal, W.; Eltabache, C.; Tweigieri, T.; Amer, S.B. Robust expression of tumor suppressor miRNA's let-7 and miR-195 detected in plasma of Saudi female breast cancer patients. BMC Cancer 2017, 17, 799. [CrossRef] [PubMed]

65. Fan, T.; Mao, Y.; Sun, Q.; Liu, F.; Lin, J.S.; Liu, Y.; Cui, J.; Jiang, Y. Branched rolling circle amplification method for measuring serum circulating microRNA levels for early breast cancer detection. Cancer Sci. 2018, 109, 2897-2906. [CrossRef]

66. Niedźwiecki, S.; Piekarski, J.; Szymańska, B.; Pawłowska, Z.; Jeziorski, A. Serum levels of circulating miRNA-21, miRNA-10b and miRNA-200c in triple-negative breast cancer patients. Ginekol. Pol. 2018, 89, 415-420. [CrossRef]

67. Souza, K.C.B.; Evangelista, A.F.; Leal, L.F.; Souza, C.P.; Vieira, R.A.; Causin, R.L.; Neuber, A.C.; Pessoa, D.P.; Passos, G.A.S.; Reis, R.M.V.; et al. Identification of Cell-Free Circulating MicroRNAs for the Detection of Early Breast Cancer and Molecular Subtyping. J. Oncol. 2019, 2019, 8393769. [CrossRef]

68. Chen, Y.; Wu, N.; Liu, L.; Dong, H.; Wu, C. Correlation between microRNA-21, microRNA-206 and estrogen receptor, progesterone receptor, human epidermal growth factor receptor 2 in breast cancer. Clin. Biochem. 2019, 71, 52-57. [CrossRef]

69. Ozawa, P.M.M.; Vieira, E.; Lemos, D.S.; Souza, I.L.M.; Zanata, S.M.; Pankievicz, V.C.; Tuleski, T.R.; Souza, E.M.; Wowk, P.F.; Urban, C.A.; et al. Identification of miRNAs Enriched in Extracellular Vesicles Derived from Serum Samples of Breast Cancer Patients. Biomolecules 2020, 10, 150. [CrossRef]

70. Li, Q.; Liu, M.; Ma, F.; Luo, Y.; Cai, R.; Wang, L.; Xu, N.; Xu, B. Circulating miR-19a and miR-205 in serum may predict the sensitivity of Luminal A subtype of breast cancer patients to neoadjuvant chemotherapy with epirubicin plus paclitaxel. PLoS ONE 2014, 9, e104870. [CrossRef] 
71. Müller, V.; Gade, S.; Steinbach, B.; Loibl, S.; von Minckwitz, G.; Untch, M.; Schwedler, K.; Lübbe, K.; Schem, C.; Fasching, P.A.; et al. Changes in serum levels of miR-21, miR-210, and miR-373 in HER2-positive breast cancer patients undergoing neoadjuvant therapy: A translational research project within the Geparquinto trial. Breast Cancer Res. Treat 2014, 147, 61-68. [CrossRef] [PubMed]

72. Li, H.; Liu, J.; Chen, J.; Wang, H.; Yang, L.; Chen, F.; Fan, S.; Wang, J.; Shao, B.; Yin, D.; et al. A serum microRNA signature predicts trastuzumab benefit in HER2-positive metastatic breast cancer patients. Nat. Commun. 2018, 9, 1614. [CrossRef] [PubMed]

73. Badr, M.; Said, H.; Louka, M.L.; Elghazaly, H.A.; Gaballah, A.; Atef Abd El Mageed, M. MicroRNA-21 as a predictor and prognostic factor for trastuzumab therapy in human epidermal growth factor receptor 2-positive metastatic breast cancer. J. Cell Biochem. 2019, 120, 3459-3466. [CrossRef] [PubMed]

74. Rodríguez-Martínez, A.; de Miguel-Pérez, D.; Ortega, F.G.; García-Puche, J.L.; Robles-Fernández, I.; Exposito, J.; Martorell-Marugan, J.; Carmona-Sáez, P.; Garrido-Navas, M.D.C.; Rolfo, C.; et al. Exosomal miRNA profile as complementary tool in the diagnostic and prediction of treatment response in localized breast cancer under neoadjuvant chemotherapy. Breast Cancer Res. 2019, 21, 21. [CrossRef] [PubMed]

75. Yang, F.; Fu, Z.; Yang, M.; Sun, C.; Li, Y.; Chu, J.; Zhang, Y.; Li, W.; Huang, X.; Li, J. Expression pattern of microRNAs related with response to trastuzumab in breast cancer. J. Cell Physiol. 2019, 234, 16102-16113. [CrossRef] [PubMed]

76. Liu, B.; Su, F.; Lv, X.; Zhang, W.; Shang, X.; Zhang, Y.; Zhang, J. Serum microRNA-21 predicted treatment outcome and survival in HER2-positive breast cancer patients receiving neoadjuvant chemotherapy combined with trastuzumab. Cancer Chemother Pharmacol. 2019, 84, 1039-1049. [CrossRef]

77. Ritter, A.; Hirschfeld, M.; Berner, K.; Rücker, G.; Jäger, M.; Weiss, D.; Medl, M.; Nöthling, C.; Gassner, S.; Asberger, J.; et al. Circulating non-coding RNA-biomarker potential in neoadjuvant chemotherapy of triple negative breast cancer? Int. J. Oncol. 2020, 56, 47-68. [CrossRef]

78. McGuire, A.; Casey, M.C.; Waldron, R.M.; Heneghan, H.; Kalinina, O.; Holian, E.; McDermott, A.; Lowery, A.J.; Newell, J.; Dwyer, R.M.; et al. Prospective Assessment of Systemic MicroRNAs as Markers of Response to Neoadjuvant Chemotherapy in Breast Cancer. Cancers 2020, 12, 1820. [CrossRef]

79. Bautista-Sánchez, D.; Arriaga-Canon, C.; Pedroza-Torres, A.; De La Rosa-Velázquez, I.A.; González-Barrios, R.; Contreras-Espinosa, L.; Montiel-Manríquez, R.; Castro-Hernández, C.; Fragoso-Ontiveros, V.; Álvarez-Gómez, R.M.; et al. The Promising Role of miR-21 as a Cancer Biomarker and Its Importance in RNA-Based Therapeutics. Mol. Ther. Nucleic Acids 2020, 20, 409-420. [CrossRef]

80. Kashyap, D.; Kaur, H. Cell-free miRNAs as non-invasive biomarkers in breast cancer: Significance in early diagnosis and metastasis prediction. Life Sci. 2020, 246, 117417. [CrossRef]

81. Najjary, S.; Mohammadzadeh, R.; Mokhtarzadeh, A.; Mohammadi, A.; Kojabad, A.B.; Baradaran, B. Role of miR-21 as an authentic oncogene in mediating drug resistance in breast cancer. Gene 2020, 738, 144453. [CrossRef] [PubMed]

82. Huang, Q.; Song, Q.; Zhong, W.; Chen, Y.; Liang, L. MicroRNA-10b and the clinical outcomes of various cancers: A systematic review and meta-analysis. Clin. Chim. Acta. 2017, 474, 14-22. [CrossRef] [PubMed]

83. Browne, G.; Dragon, J.A.; Hong, D.; Messier, T.L.; Gordon, J.A.; Farina, N.H.; Boyd, J.R.; VanOudenhove, J.J.; Perez, A.W.; Zaidi, S.K.; et al. MicroRNA-378-mediated suppression of Runx1 alleviates the aggressive phenotype of triple-negative MDA-MB-231 human breast cancer cells. Tumour Biol. 2016, 37, 8825-8839. [CrossRef] [PubMed]

84. Yin, J.Y.; Deng, Z.Q.; Liu, F.Q.; Qian, J.; Lin, J.; Tang, Q.; Wen, X.M.; Zhou, J.D.; Zhang, Y.Y.; Zhu, X.W. Association between mir-24 and mir-378 in formalin-fixed paraffin-embedded tissues of breast cancer. Int. J. Clin. Exp. Pathol. 2014, 7, 4261-4267.

85. Ding, W.; Fan, X.L.; Xu, X.; Huang, J.Z.; Xu, S.H.; Geng, Q.; Li, R.; Chen, D.; Yan, G.R. Epigenetic silencing of ITGA2 by MiR-373 promotes cell migration in breast cancer. PLoS ONE 2015, 10, e0135128. [CrossRef]

86. Piasecka, D.; Braun, M.; Kordek, R.; Sadej, R.; Romanska, H. MicroRNAs in regulation of triple-negative breast cancer progression. J. Cancer Res. Clin. Oncol. 2018, 144, 1401-1411. [CrossRef] 
87. Wang, M.; Zhang, H.; Yang, F.; Qiu, R.; Zhao, X.; Gong, Z.; Yu, W.; Zhou, B.; Shen, B.; Zhu, W. miR-188-5p suppresses cellular proliferation and migration via IL6ST: A potential noninvasive diagnostic biomarker for breast cancer. J. Cell Physiol. 2020, 235, 4890-4901. [CrossRef]

88. Zhu, X.; Qiu, J.; Zhang, T.; Yang, Y.; Guo, S.; Li, T.; Jiang, K.; Zahoor, A.; Deng, G.; Qiu, C. MicroRNA-188-5p promotes apoptosis and inhibits cell proliferation of breast cancer cells via the MAPK signaling pathway by targeting Rap2c. J. Cell Physiol. 2020, 235, 2389-2402. [CrossRef]

(c)

(C) 2020 by the authors. Licensee MDPI, Basel, Switzerland. This article is an open access article distributed under the terms and conditions of the Creative Commons Attribution (CC BY) license (http://creativecommons.org/licenses/by/4.0/). 